otherwise of the tumour. Examination of the tumour for stainable fat is also recommended. Furthermore, vaginal cytology for œstrogenic activity and estimation of circulating ostrogenic hormone should also be performed in laboratories where facilities for such investigations exist.

The view expressed by Novak and Woodruff (1962) in relation to the functioning properties or otherwise of Brenner tumours of the ovary appears to reflect the current trend of thought. These authors state: "We may have to revise our ideas about the inert behaviour of Brenner and other tumours in view of repeated reports of cases associated with evidence of astrogen activity. In addition, there is increasing belief that the stroma of certain tumours may be converted into cells capable of steroidal function ....We are currently willing to admit that the Brenner tumour may on occasion act in an ostrogenic role."

I wish to thank Dr. F. Calleja, Pathologist, St. Luke's Hospital, Malta, for the examination of the curettings and of the excised organs.

\section{REFERENCES}

FARRAR, H. K., and GreENE, R. R. (1960): Bilateral Brenner Tumours of the Ovary. Amer. J. Obstet. Gynec., 80, 1089.
Haines, M., and TAYlor, C. W. (1962): Gynæcological Pathology, p. 470. London: Churchill.

JondaHL, W. W., Dockerty, M. B., and Randall, L. M. (1950): Brenner Tumours of the Ovary, Amer. J. Obstet. Gynec., 60, 160.

Mackinlay, C. J. (1956): Brenner Tumours of the Ovary, J. Obstet. Gynec. Brit. Emp., 63, 158.

MeYer, R. (1931): Pathology of Some Special Ovarian Tumours and their Relation to Sex Characteristics, Amer, J. Obstet. Gynec., 12, 697.

Ming, S., and Goldman, H. (1962): Hormonal Activity of Brenner Tumours in Postmenopausal Women, Amer. J. Obstet. Gynec., 83, 666.

NovaK, E., and NovaK, E. R. (1958): Gynecologic and Obstetric Pathology. 4th Edition, p. 403. Philadelphia: W. B. Saunders.

NovaK, E. R., and Woodruff, J. D. (1962): Novak's Gynecologic and Obstetric Pathology. 5th Edition. p. 385. Philadelphia: W. B. Saunders.

SCHIFfMaN, J. (1932): Postklimakterische Blutung und Brennerscher Ovarialtumour, Arch. Gynäk., 150, 159.

ShaAban, A. J., Abdine, F. H., and Yousuf, A. F. 1960): Functioning Brenner Tumour of the Ovary, J. Obstet. Gynec. Brit. Cwlth., 67, 138.

TE LiND, R. W. (1930): Granulosa-cell Tumours of the Ovary and their Relation to Postmenopausal Bleeding, Amer. J. Obstet. Gynec., 20, 552.

\title{
ILEAL PERFORATION AND ACUTE PERIPHERAL NEUROPATHY IN RHEUMATOID ARTHRITIS
}

\author{
D. N. GoldinG*, M.D. (Dubl.), M.R.C.P.I., D.Phys.Med. \\ C. J. Goodwill, M.B. (Lond.), M.R.C.P. \\ Department of Physical Medicine and Rheumatology, The Royal Free Hospital, W.C.I.
}

Perforation of the bowel during the course of rheumatoid arthritis treated with corticosteroids has been reported on several occasions. In the following case systemic steroids had never been administered and perforation occurred together with fulminating peripheral neuritis involving all four extremities.

\section{Case Report}

A 59-year-old policeman had suffered from rheumatoid arthritis since 1953. The onset was gradual, multiple joints becoming involved, and treatment was initially conservative, employing splinting, physiotherapy, salicylates, phenylbutazone and gold to a total of 1 gram. In 1956 he had a

*Present Address-Dept. of Physical Medicine and Rheumatology, Harlow Hospital, Essex. carpal tunnel syndrome. The following year he complained of muscle pains and weakness; electromyography showed evidence of polymyositis in the small hand muscles and the urinary creatine output was $290 \mathrm{mg}$. $/ 24 \mathrm{hr}$. In January 1962 he complained of increased muscular pain and weakness, although the disease in the joints at this time was only moderately active. Eleven months later he had numbness and burning pain in hoth feet and then in the hands and at this time he complained of colicy abdominal pain and diarrhoea, with blood in the stools on one occasion. He had lost one stone $(6.5 \mathrm{Kg}$.) in weight during the previous 3 months.

He was admitted to the Royal Free Hospital on 15th January, 1963, when examination revealed moderately active rheumatoid arthritis with subcutaneous nodules and wasting of the forearm and small hand muscles. There was bilateral, nearly symmetrical weakness of the arms and legs, all the deep reflexes were greatly diminished and there was loss 


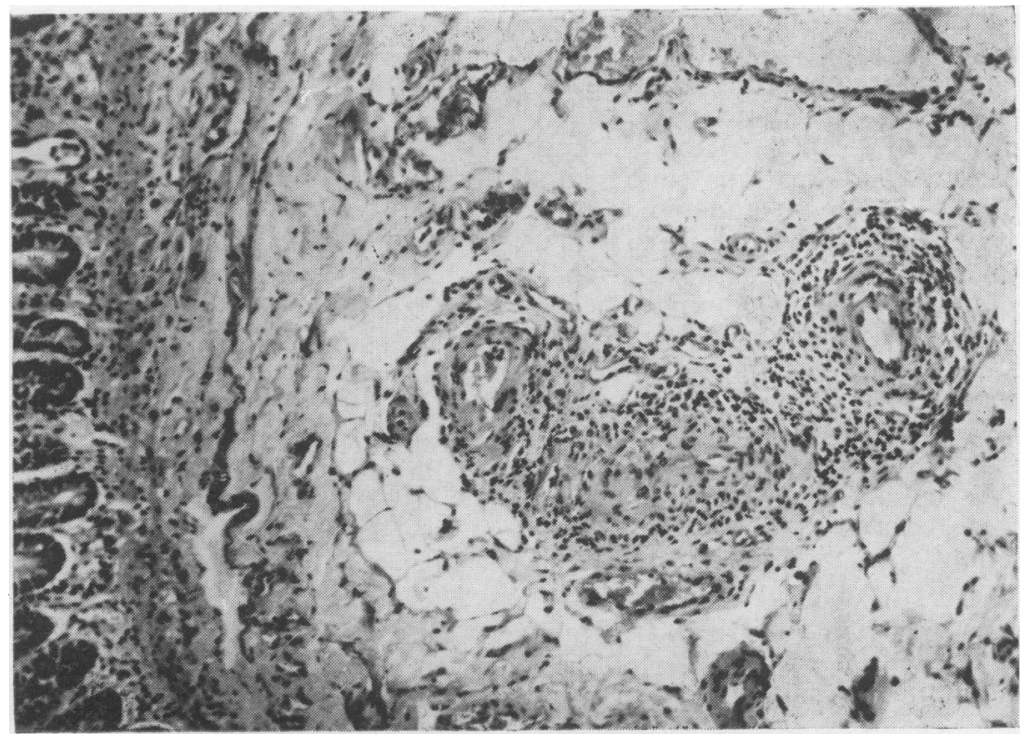

FIG. 1.-Section of intestinal wall showing panarteritis of several small arteries in the submucosa and endarteritis obliterans in one of these.

of all forms of sensation below the elbows and knees. The peripheral arterial pulses were present and equal. The liver and spleen were not enlarged and abdominal examination was negative except for slight generalised tenderness.

Investigations. Hb. 10.1 g. $/ 100 \mathrm{ml}$. WBC $11,400 / \mathrm{cu}$. mm., differential normal, ESR $55 \mathrm{~mm}$./hr. (Westergren), Serum proteins: total $6.0 \mathrm{~g} . / 100 \mathrm{ml}$., albumin 3.2 g., globulin 2.8 g., electrophoresis showed moderately raised alpha-2, beta and gamma globulin. Urinary porphyrins not detected. Stool culture negative. CSF : clear fluid, protein $25 \mathrm{mg} . / 100 \mathrm{ml}$., cells $1 / \mathrm{cu}$. mm. Rose test positive $(1: 256)$, latex test positive. ECG showed right bundle branch block (unchanged since 1961). Radiographs of the hands showed the changes of moderately severe rheumatoid arthritis, the metacarpo-phalangeal joints being principally affected with erosions and subluxations. Chest $\mathrm{X}$-ray normal. A barium enema was reported as showing marked diverticulitis in the sigmoid and descending colon.

The weakness and anæsthesia spread proximally, so that three days after admission he had bilateral foot-drop and wrist-drop. The diarrhoea and intermittent abdominal colic continued. On 2.2 .63 he complained of very severe lower abdominal pain and the abdomen was now extremely tender and hyperresonant. A laparotomy was performed (Mr. L. R. H. Gracey): oval yellow ulcers, some of which had perforated, were seen in the ileum. All the welldeveloped and perforated ulcers were oversewn and the abdomen was closed. Two hours later the patient suddenly became very dyspnœic and cyanosed, and he died within an hour.

Necropsy. The peritoneal cavity contained about 1 1. of turbid green fluid with early peritonitis. There were multiple areas of ulceration in the ileum, confined to the Peyer's patches. The colon showed ulceration of the solitary lymphoid follicles. No abnormality was apparent in the liver, spleen or lymph-nodes.

Sections of the ileum showed abscess cavities in the muscle layer, a typical one being lined by fibrin with a polymorphonuclear zone and an outer layer of organizing granulation tissue. There was no evidence of typhoid. Small arteries showing inflanf $\overrightarrow{0}$ matory changes appeared in apposition to these of necrotic areas (Fig. 1). The walls of the arteries were. infiltrated with many lymphocytes and plasma cells the media being disorganised with areas of fibrinor necrosis and sometimes complete obliteration of the lumen. Sections of the vasa nervorum of the sciatic nerve showed changes which were even more marked than those in the intestinal vessels.

\section{Discussion}

This patient had classical rheumatoid arthritis (Ropes, Bennett, Cobb, Jacox and Jessar, 1958) with subcutaneous nodules and positive sheep-cell agglutination and latex fixation tests. Except for 흘 evidence of myositis in the small muscles of the hands, there was nothing unusual in the course of $\dot{\sigma}$ the disease until the onset of peripheral neuritis in December 1962 followed shortly afterwards by 8 abdominal pain and diarrhœa, with blood in the $₹$ stools. He had never received systemic cortico- 0 steroids. Histological examination provided unequivocal evidence that the intestinal lesions caus- $\frac{7}{0}$ ing perforation were due to necrotising arteritis. The lesions were unusual in that they predomin- o antly involved the Peyer's patches of the ileum, the appearance at laparatomy closely resembling 0 typhoid ulceration. However, cultures for $\mathbb{\omega}$ Salmonella in the stools were negative and the 0 histology of the intestine was not that of typhoid.

Intestinal arteritis with perforation, gangrene $\stackrel{\odot}{\overparen{D}}$ or severe hæmorrhage has frequently been $\stackrel{\mathcal{D}}{\rightarrow}$ reported in association with rheumatoid arthritis :treated with corticosteroids (Table 1) and usually has been attributed to these drugs rather than to $\overrightarrow{\mathbb{D}}$ the rheumatoid process itself. One patient has 
TABLE 1

Previously Reported Abdominal Emergencies Due TO INTESTINAL INVOLVEMENT IN RHEUMATOID

\section{ARTHRITIS}

Authors No. of cases

Adler and others 2: 1 small intestinal perfora(1962)

Bradley (1954) 1: perforation of sigmoid colon

Hingorani \& Graham 1: gangrene of small bowel (1963)

Kemper and others 1: intestinal hæmorrhage (1957)

Levin and others (1953)

Parker \& Thomas (1959)

Stolzer and others (1957)

West \& Newns (1953)

2: 1 intestinal perforation 1 gangrene of bowel

2: 1 perforation of sigmoid colon

1 perforation of cæcum

1: perforation of colon

1: intestinal hæmorrhage

been recorded with perforation of the bowel who had not received systemic steroids (Adler, Norcross and Lockie, 1962), but in none of the previously reported cases has ulceration and perforation of the Peyer's patches been particularly mentioned. It seems that whereas perforation is more likely to occur in those patients who have had systemic steroids, this complication occasionally arises in patients with rheumatoid arthritis who have not received them. It is generally thought that arteritis in rheumatoid arthritis occurs more frequently when corticosteroids are used: Kemper, Baggenstross and Slocumb (1957) in post-mortem examinations of 52 patients with the disease found arteritis in 4 out of the 14 who had had steroids, but there was no evidence of vascular disorder in the remaining 38 patients; Schmid, Cooper, Ziff and McEwen (1961) in a review of arteritis in rheumatoid arthritis described 9 cases with peripheral neuropathy, 7 of whom had received steroids.

In this case there was widespread arteritis, including involvement of peripheral nerves. The occurrence of neuropathy in rheumatoid arthritis is well known (Hart \& Golding, 1960; Steinberg, 1960), patients with this complication usually being males with severe seropositive arthritis, a predominantly sensory polyneuritis and involvement of the legs more than the arms. Rapidly ascending polyneuritis such as in this case has not been reported other than in patients previously treated with systemic steroids.

While this patient clearly had rheumatoid arthritis, the occurrence of peripheral neuropathy raises the possibility of another collagen disease, in particular polyarteritis nodosa. Rose and Spencer (1957) reported this complication in 24 of 111 cases of polyarteritis nodosa, seven of them showing arteritis of the nerves. However, it is noteworthy that a further 8 cases in this series had a rheumatoid type of arthritis but no neuropathy. Walton (1958) reported peripheral neuropathy in 16 of 56 cases of Wegener's granulomatesis, necrotising arteritis being found in the peripheral nerves in 4 . Several reported cases of systemic lupus erythematosus, particularly those of Heptinstall and Sowry (1952) and of Bailey, Sayre and Clark (1956), had peripheral neuropathy of a symmetrical or mononeuritis multiplex type. This complication has also been reported in scleroderma (Kibler and Rose, 1960). Histologically, the arterial lesions in the case described resembled those of polyarteritis nodosa, in which intestinal perforation occurs not uncommonly (Friedman, Schwartz, Truben and Steinbrocker, 1953; Rabinovitch and Rabinovitch, 1954; McKeown and Ganguli, 1956). However, this patient had classical rheumatoid arthritis and it is known that the necrotising arteritis of rheumatoid arthritis may closely simulate the vascular lesions of polyarteritis nodosa, although the necrosis is usually less severe and aneurysm formation is said never to occur (Cruikshank, 1954).

It is important to recognise the significance of sudden development of abdominal pain with constipation or diarrhœa in any patient with rheumatoid arthritis, especially if there is other evidence of vasculitis such as polyneuritis, arteritic lesions of the skin or peripheral gangrene. In these circumstances the patient should be regarded as having widespread necrotizing vasculitis, and if the symptoms persist or rapidly increase laparotomy and resection of the involved segments of bowel should be seriously considered.

\section{Summary}

The case is reported of a 59-year-old man with rheumatoid arthritis who had never received systemic corticosteroids, and who developed fatal intestinal arteritis and perforation together with ascending polyneuritis.

We wish to thank Dr. A. T. Richardson for permission to report this case, and Dr. I. P. Beswick for advice on the pathological findings.

\section{REFERENCES}

Adler, R. H., Norcross, B. M., and Lockie, L. M. (1962): Arteritis and Infarction of the Intestine in Rheumatoid Arthritis, J. Amer. med. Ass., 180, 922.

Bailey, A. A., Sayre, G. P., Clark, E. C. (1956): Neuritis Associated with Systemic Lupus Erythematosus, A.M.A. Arch. Neurol. Psychiat., 75, 251.

BRADLey, R. L. (1954): Spontaneous Perforation of Sigmoid with Fatal Outcome during Cortisone therapy, W. Va. med. J., 50, 148.

Cruickshank, B. (1954): The Arteritis of Rheumatoid Arthritis, Ann. rheum. Dis., 13, 136.

Friedman, H. H., Schwartz, S., Truber, M., STEINBROCKER, O. (1953): The Pararheumatic Arthropathies, Ann. intern. Med., 38, 732. 
HART, F. D., Golding, J. R. (1960): Rheumatoid Neuropathy, Brit. med. J., i, 1594.

Hingorani, K., and GrahaM, G. S. (1963): Smallbowel Necrosis due to Arteritis in Rheumatoid Disease, Ann. phys. Med., 7, 68.

Heptinstall, R. H., and Sowry, G. S. C. (1952): Peripheral Neuritis in Systemic Lupus Erythematosus, Brit. med. J., i, 525.

Kemper, J. W., Baggenstross, A. H., and Slocumb, C. H. (1957): The Relationship of Therapy with Cortisone to the Incidence of Vascular Lesions in Rheumatoid Arthritis, Ann. intern. Med., 46, 831.

KIBleR, R. F., and Rose, F. C. (1960): Peripheral Neuropathy in the Collagen Diseases. A case of Scleroderma Neuropathy, Brit. med. J., i, 1781.

LeVIN, M. H., Rivo, J. B., SCOTT, W., FigueroA, W. G., Fred, L., and BARreTt, T. F. (1953): The Prolonged Treatment of Rheumatoid Arthritis with Cortisone and Corticotrophin, Amer. J. Med., 14, 265.

McKeown, K. C., and Ganguli, A. K. (1956): Gastro-Intestinal Symptoms in Polyarteritis Nodosa, Brit. J. Surg., 44, 308.

Parker, R. A., and Thomas, P. M. (1959): Intestinal Perforation and Widespread Arteritis in Rheuma- toid Arthritis during Treatment with Cortisone, 으 Brit. med. J., i, 540.

Rabinovitch, J., and Rabinovitch, S. (1954): In- $\mathbb{\Phi}$ farction of the Small Intestine sequent to Poly- $c$ arteritis of the Mesenteric Vessels, Amer. J. Surg., 88, 896.

Ropes, M. W., Bennett, G. A., CoBb, S., Jacox, R., $\stackrel{\text { 号 }}{\rightarrow}$ and Jessar, R. A. (1958): Diagnostic Criteria for Rheumatoid Arthritis, Bull. rheum. Dis., 9, 175.

ROSE, G. A., and SPENCER, H. (1957): Polyarteritis $\frac{\bar{\rho}}{J}$ Nodosa, Quart. J. Med., 26, 43.

SCHMID, F. R., COOPER, N. S., ZIFF, M., and $\varrho$ MCEWEN, C. (1961): Arteritis in Rheumatoid कै Arthritis, Amer. J. Med., 30, 56.

STEINBERG, V. L. (1960): Neuropathy in Rheumatoid $\vec{\circ}$ Disease, Brit. med. J., i, 1600.

Stolzer, B. L., BARR, J. H., EISEnbeis, C. H., $\vec{\omega}$ WeChSler, R. L., and Margolis, H. M. (1957): Prednisone and Prednisolone Therapy in Rheuma-ce toid Arthritis, J. Amer. med. Ass., 165, 13.

Walton, E. W. (1958): Giant-cell Granuloma of the Respiratory Tract (Wegener's Granulomatosis), $\stackrel{ \pm}{\rightarrow}$ Brit. med. J., ii, 265.

WEST, H. F., and Newns, G. R. (1953): Cortisone and Rheumatoid Disease, Lancet, ii, 1123

\section{EOSINOPHILIC INFILTRATION OF THE STOMACH AND DUODENUM COMPLICATED BY PERFORATION}

\author{
J. Y. W. Russell, M.B., Ch.B., F.R.C.S.E. \\ Consultant Surgeon. \\ Preston \& Chorley Hospitals
}

\author{
G. Evangelou, M.D. \\ Resident Surgical Officer. \\ Chorley \& District Hospital
}

THE PRESENCE of diffuse thickening of the stomach and duodenum and also of the upper part of the small intestine due to eosinophilic infiltration has been observed during recent years by several authors and the condition is now very well documented. Bockus (1963) has reviewed the condition extensively. The following case is reported as it may be unique in that the infiltration was associated with perforation.

\section{Case Report}

The patient, Mr. R.H., aged 45 , a bus inspector, was admitted to hospital as an emergency on 5.3.63 with severe abdominal pain and vomiting. His pain had begun suddenly at 4 a.m. It was located initially in the right iliac fossa but it had soon spread to become generalised over the whole obdomen. Vomiting had occurred soon after the onset of the pain and had recurred twice, the vomitus being watery and copious. He had had a normal bowel action on the day prior to admission.

He gave a history of chronic bronchitis of many years duration. In association with this, hæmoptysis had occurred on two occasions. Some twelve years previously, he had developed a contact dermatitis with motor oil and he was obliged to change his job. More recently he had had some upper abdominal discomfort. He reported this to his family doctor on the day prior to admission and he was found to have some upper abdominal tenderness. Gall bladder pathology was suspeoted.

On examination he was obviously in great pain; pulse 92 , temperature $96^{\circ} \mathrm{F}$. His tongue was moist and clean. The abdomen was held rigidly with very little movement on respiration and was diffusely guarded and tender with marked rebound tenderness. The liver dullness was not diminished. Rectal cxamination was negative. A few adventitious sounds were heard in the chest but air entry was reasonably good.

Investigations: Hb. $120 \%$, PCV $61 \%$, MCHC $29 \%$, WBC $20,000 / \mathrm{cu}$. mm. with a polymorphonuclear leucocytosis. An X-ray of the chest showed some linear shadowing at both bases suggesting possible lower lobe shrinkage or minimal inflammatory change. A plain film of the abdomen revealed the presence of a pneumoperitoneum with apparently normal bowel shadows. An emergency operation was decided upon with a provisional diagnosis of perforation of a peptic ulcer.

Operation (5.3.63). Exploration under general anæsthesia was carried out through an upper right paramedian incision. On opening the peritoneum a considerable quantity of free turbid fluid was encountered and this was aspirated. A large per- 